\title{
PERENCANAAN AREAL PARIWISATA BERDASARKAN ISU DAN POTENSI LOKAL DI DESA TANAH LEMO, KECAMATAN BONTOBAHARI, KABUPATEN BULUKUMBA, PROVINSI SULAWESI SELATAN
}

\author{
Tourism Area Planning Based on Issues and Local Potency in Tanah Lemo \\ Village, Bontobahari District, Bulukumba Regency, South Sulawesi Province
}

\section{Setyardi Pratika Mulya1)*, Nurkhusnul Inayah Jusman ${ }^{2)}$ dan Andrea Emma Pravitasari1)}

\author{
1) Departemen Ilmu Tanah dan Sumberdaya Lahan, Fakultas Pertanian IPB University, Jl. Meranti Kampus IPB \\ Darmaga Bogor 16680 \\ 2) Program Studi Manajemen Sumberdaya Lahan, Departemen Ilmu Tanah dan Sumberdaya Lahan, Fakultas \\ Pertanian IPB University, Jl. Meranti Kampus IPB Darmaga Bogor 16680
}

\begin{abstract}
Based on the Spatial Planning (RTRW) of Bulukumba Regency in 2018-2038, tourism is the primary sector, and Tanah Lemo Village is the tourism development plan's location. Lemo-Lemo Beach is one of the undeveloped coastal tourist destinations in Bulukumba Regency. This study aims to identify land use in 2019, analyze land rent of each land use, determine land priorities for tourism development, and identify strategies for developing Lemo-Lemo Beach Tourism. The data used are google earth imagery, spatial pattern maps (Bappeda), parcels of land (BPN), degraded land (Bappeda), agricultural direction (BBSDLP), slope (BIG), and so forth, as well as the results of the interview respondents. The methods used in this study are visual interpretation and classification of land cover, land rent analysis, determination of the land priority level for tourism development, and SWOT analysis. The results showed that 11 types of land use in the study location were water bodies, ponds, emplacement, high-density forests, low-density forests, mixed gardens, open land, high-density settlements, medium-density settlements, shrubs, and fields. The largest land use is a moor. The largest land rent value is high-density settlements of Rp. $150,458 / \mathrm{m} 2$ / year (low). Based on the priority level of land for the development of tourist areas, a priority 1 is 49 ha (1.7\%). The strategy of developing Lemo-Lemo Beach tourism is by promoting tourism, including by hosting local or national tourism festival activities, developing spring tourism, community forest parks, cultural sites, and developing alternative tourism options, for example, playgrounds/outbound and others so. Tanah Lemo Village has the potential for future tourism development, and Lemo-Lemo Beach is a new source of regional income in the tourism sector.
\end{abstract}

Keywords: Land rent, Land Priority, Land Use, SWOT

ABSTRAK

Berdasarkan Rencana Tata Ruang Wilayah (RTRW) Kabupaten Bulukumba tahun 2018-2038, pariwisata merupakan sektor utama dan Desa Tanah Lemo merupakan lokasi rencana pengembangan wisata daerah. Pantai Lemo-Lemo merupakan salah satu destinasi wisata pantai di Kabupaten Bulukumba yang belum berkembang. Penelitian ini bertujuan untuk mengidentifikasi penggunaan lahan tahun 2019, menganalisis land rent setiap penggunaan lahan, menentukan prioritas lahan untuk pengembangan kawasan wisata, dan mengidentifikasi strategi pengembangan Kawasan Wisata Pantai Lemo-Lemo. Data yang digunakan adalah citra google earth, peta pola ruang (Bappeda), peta persil dan bidang tanah (BPN), peta lahan kritis (Bappeda), peta arahan pertanian (BBSDLP), kemiringan lereng (BIG) serta hasil wawancara responden. Metode yang digunakan adalah interpretasi visual dan klasifikasi tutupan lahan (SIG), analisis landrend, penentuan tingkat prioritas lahan untuk pengembangan kawasan wisata (matrik), dan analisis SWOT. Hasil penelitian menunjukkan terdapat 11 jenis penggunaan lahan yaitu badan air, empang, emplasment, hutan berkerapatan tinggi, hutan berkerapatan rendah, kebun campuran, lahan terbuka, permukiman kerapatan padat, permukiman kerapatan sedang, semak belukar dan tegalan. Penggunaan lahan terluas adalah tegalan $(1,411.1 \mathrm{ha} / 48.7 \%)$. Nilai land rent terbesar adalah permukiman penduduk padat sebesar $\mathrm{Rp} .150 .458 / \mathrm{m}^{2} / \mathrm{tahun}$. Berdasarkan tingkat prioritas lahan untuk pengembangan kawasan wisata, prioritas I seluas 49 ha (1.7\%). Strategi pengembangan kawasan wisata Pantai Lemo-Lemo adalah menggiatkan promosi wisata, diantaranya dengan menjadi tuan rumah kegiatan festival wisata lokal atau nasional, mengembangkan wisata mata air yang belum banyak diketahui, taman hutan rakyat, situs budaya dan mengembangkan alternatif wisata buatan, misalnya taman bermain/outbound. Desa Tanah Lemo memiliki potensi pengembangan pariwisata dan menjadi sumber pendapatan daerah di sektor pariwisata pada masa mendatang.

Kata kunci:, Land rent, Prioritas Lahan, Penggunaan Lahan, SWOT

\section{PENDAHULUAN}

Sektor pariwisata sebagai salah satu strategi dari akselerasi pertumbuhan ekonomi nasional (RPJMN 2015-
2019). Kontribusi yang diberikan sektor pariwisata diantaranya melalui penerimaan devisa, pendapatan daerah, pengembangan wilayah, maupun dalam penyerapan investasi dan tenaga kerja serta pengembangan usaha yang 
tersebar di berbagai pelosok wilayah di Indonesia (LPEM UI, 2018). Dalam kontek pengembangan wilayah harus mempertimbangkan aspek-aspek secara komprehensif (ekologi, sosial, ekonomi, budaya), seperti halnya perencanaan pada sektor lainnya (Kantola et al., 2018, Rahmafitria et al., 2020) atau dikenal dengan istilah "Sustainable Tourism" (Blancas et al., 2011; Oyola et al., 2012). Kondisi eksisting lokasi studi masih alami dan terjaga, dengan karakteristik sosial masyarakat yang masih memegang erat budaya lokal (adat).

Berdasarkan Rencana Tata Ruang Wilayah (RTRW) Kabupaten Bulukumba tahun 2018-2038 Desa Tanah Lemo merupakan bagian dari rencana pengembangan destinasi pariwisata Kabupaten Bulukumba ke depan. Pariwisata pesisir dan laut saat ini menjadi salah satu segmen terbesar dari sektor ekonomi maritim serta komponen terbesar dari industri pariwisata pesisir dan laut. Namun demikian pariwisata pesisir (pantai) juga sering menimbulkan kontroversi mengenai dampak lingkungan dan kesesuaian dengan kegiatan lainnya (Papageorgiou, 2016, Mai et al., 2018), Pantai Lemo-Lemo saat ini kondisinya masih asri, namun sudah mulai adanya penurunan kualitas lingkungan, misalnya karena sampah. Selain itu, fenomena lahan di lokasi studi adalah terjadinya perubahan lahan (land use change), baik dari hutan menjadi lahan pertanian maupun lahan pertanian menjadi lahan terbangun. Perubahan penggunaan lahan ber-vegetasi menjadi lahan terbangun (Supriatna et al., 2016) dalam pengembangan destinasi pariwisata di Desa Lemo-Lemo tidak dapat dihindari. Perubahan lahan tersebut terjadi karena adanya keperluan untuk memenuhi kebutuhan pengembangan areal pariwisata dan kebutuhan hunian penduduk di sekitar kawasan wisata yang semakin meningkat (Ante et al., 2016). Salah satu destinasi pariwisata pesisir yang berpotensi untuk dikembangkan di lokasi penelitian adalah Pantai LemoLemo, sehingga diperlukan proses perencanaan penggunaan lahan dan pariwisata yang komprehensif (Maguidad, 2013)

Untuk mendukung pengembangan kawasan pariwisata di Desa Tanah Lemo, khususnya di Pantai LemoLemo, maka perlu adanya penelitian mengenai perencanaan prioritas lahan dan penentuan strategi untuk pengembangan wisatanya. Perspektif pemangku kepentingan yang beragam terhadap perencanaan ruang (kawasan pariwisata) dan konservasi alam sering menimbulkan konflik (Almeida $e t$ al., 2017). Dilema peningkatan pendapatan (ekonomi) daerah (Lai et al., 2006) dan aspek konservasi sering terjadi bagi pemangku kepentingan (Pemerintah Daerah). Selain itu, kesenjangan antara perencanaan dan implementasi juga sering menimbulkan masalah di lapangan. Dengan demikian, penelitian ini penting dilakukan karena dapat memberikan arahan kepada pemerintah daerah dan masyarakat yang akan mengembangkan wilayah ini. Dengan perencanaan yang baik, diharapkan dapat memberikan alternatif destinasi wisata unggulan di Kabupaten Bulukumba.

\section{Tujuan Penelitian}

Penelitian ini bertujuan untuk 1) mengidentifikasi penggunaan lahan tahun 2019,2 ) menganalisis land rent setiap penggunaan lahan 3) menentukan prioritas areal pengembangan kawasan wisata (pantai) berdasarkan eksisting, potensi, dan kebijakan lahan, dan 4) menyusun strategi pengembangan kawasan Pantai Lemo-Lemo.

\section{BAHAN DAN METODE}

Lokasi penelitian adalah Desa Tanah Lemo, Kecamatan Bontobahari, Kabupaten Bulukumba, Provinsi Sulawesi Selatan (Gambar 1). Penelitian dilaksanakan dari bulan Januari sampai bulan Juli 2019.

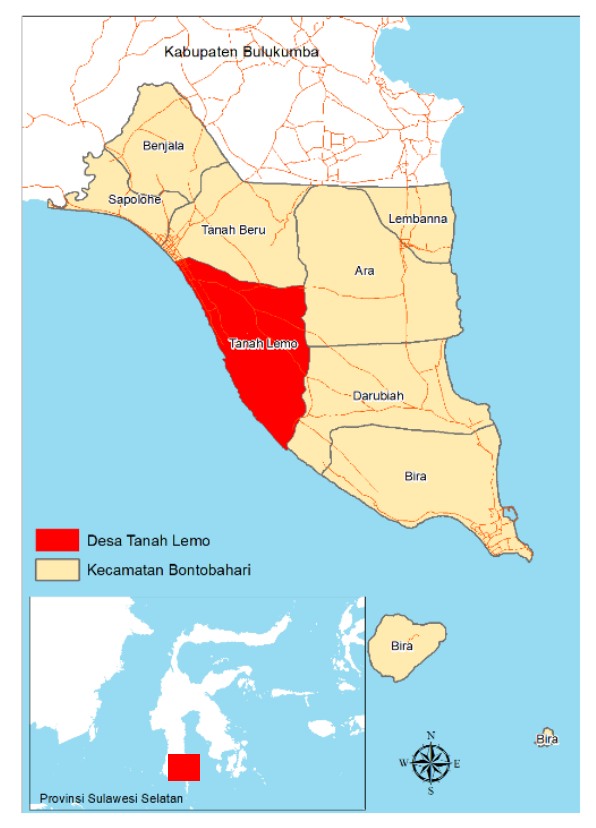

Gambar 1. Peta lokasi penelitian Desa Tanah Lemo, Kecamatan Bontobahari, Provinsi Sulawesi Selatan

\section{Data dan Bahan Penelitian}

Jenis data yang digunakan dalam penelitian adalah data primer dan sekunder. Data primer yang digunakan berupa data hasil wawancara (responden) untuk analisis land rent, dan data penggunaan lahan eksisting berupa pengamatan lapang. Data sekunder berupa data instansial, dan diperoleh dari berbagai instansi di daerah dan studi literatur. Data tersebut di antaranya citra google earth tahun 2018, profil Pantai Lemo-Lemo (Dinas Pariwisata Kabupaten Bulukumba), data persil (BPN), serta peta dan dokumen RTRW Kabupaten Bulukumba Tahun 2018-2023 (Badan Perencanaan Pembangunan Daerah (BAPPEDA) Kabupaten Bulukumba). Peralatan yang digunakan yaitu komputer dengan perangkat lunak berupa software ArcGIS 10.3, Microsoft Office, Microsoft Excel, Global Positioning System (GPS), kuesioner, kamera untuk pengamatan lapang dan alat tulis.

\section{Metodologi}

\section{Identifikasi Penggunaan Lahan Desa Tanah Lemo Tahun 2019}

Klasifikasi tutupan lahan dilakukan dengan interpretasi visual (manual) citra google earth tahun 2018 dengan bantuan software ArcGIS seri 10.3 pada skala digitasi 1:10.000. Sebelumnya, citra google earth dikoreksi 
geometri dan selanjutnya dilakukan interpretasi. Interpretasi citra pada penelitian ini menggunakan nomenklatur klasifikasi tutupan lahan berdasarkan Standar Nasional Indonesia (SNI) 7645-2010 dan dilakukan pendetilan/modifikasi klasifikasi SNI. Nomenklatur klasifikasi tutupan lahan berikut definisinya sesuai disajikan pada Tabel 1.

Klasifikasi dilakukan dengan mengacu pada unsurunsur interpretasi menurut Lillesand et al., (2004) dan Susanto (1986), yaitu (1) rona (tone/color tone/grey tone) (2) warna (3) bentuk, (4) ukuran (5) tekstur, (6) pola (7) situs. Unsur-unsur tersebut akan sangat mempengaruhi penentuan jenis tutupan atau penggunaan lahan.

\section{Menghitung Nilai Land rent Tiap Penggunaan Lahan}

Dalam perencanaan lahan, nilai land rent sangat penting diketahui sebagai sumber informasi awal maupun bagian dari proses perencanaannya. Menurut Rustiadi et al., 2011, land rent terbagi menjadi 3 (tiga) economic rent, environmental rent dan social rent. Penelitian ini fokus pada aspek economic rent tiap penggunaan lahan atau biasa disebut land rent (LR). Economic rent adalah surplus ekonomi untuk setiap penggunaan lahan, baik pertanian maupun non-pertanian dengan satuan $\mathrm{Rp} / \mathrm{m}^{2} /$ tahun (Mulya, et al., 2019). Faktor lahan mampu menghasilkan economic rent yang dapat menjadi penentu keunggulan komparaif suatu wilayah (Czyzewski e al 2016).

Data untuk analisis land rent diperoleh dari wawancara di lapangan, diantaranya input (harga beli, pendapatan dari produksi dari pemanfaatan lahan), output (harga jual/sewa, pengeluaran listrik, air, pengeluaran dari pemanfaatan lahan). Responden setiap penggunaan lahan, masing-masing satu orang. Alat yang digunakan adalah formulir (kuesioner), alat tulis dan kamera. Nilai land rent memiliki satuan $\mathrm{Rp} / \mathrm{m}^{2}$ / tahun dan dihitung dengan rumus:

$$
\text { Land Rent }\left(\frac{\frac{R p}{m^{2}}}{\text { year }}\right)=\frac{T R(R p)-T E(R p)}{L A\left(m^{2}\right)}
$$

di mana, TR = total penerimaan (produksi, harga, pendapatan) $(\mathrm{Rp})$; $\mathrm{TE}=$ total pengeluaran (biaya produksi, distribusi, layanan) (Rp); LA = jumlah luas $\left(\mathrm{m}^{2}\right)$ (Mulya, et al., 2019).

\section{Penentuan Prioritas Lahan untuk Pengembangan Kawasan Wisata (TPPkw)}

Penentuan prioritas lahan untuk pengembangan kawasan wisata di Desa Tanah Lemo dilakukan dengan skoring. Setiap parameter memiliki nilai skor yang nantinya akan diakumulasikan. Semakin besar skor/jumlah skor menunjukkan semakin prioritas lahan tersebut. Parameter yang digunakan dapat dibagi menjadi 4 kategori (jenis), yaitu 1). kebijakan lahan terdiri dari pola ruang, persil tanah, status tanah, dan status kawasan hutan, 2). potensi lahan, terdiri dari arahan lahan, 3). mitigasi bencana, terdiri dari lahan kritis dan rawan tsunami,4). eksisting, terdiri dari tutupan lahan, dan kemiringan lereng (Tabel 2 dan Gambar 2).

Tabel 1. Klasifikasi tutupan lahan berdasarkan SNI (modifikasi) beserta definisi

\begin{tabular}{|c|c|c|}
\hline No & Tutupan Lahan & Definisi \\
\hline 1 & $\begin{array}{l}\text { Hutan } \\
\text { berkerapatan tinggi }\end{array}$ & $\begin{array}{l}\text { Hutan dengan kerapatan antar pohon tinggi. Diinterpretasi berwarna hijau tua dengan tekstur kasar dan pola berkelompok. Bisa } \\
\text { berwarna hijau lebih gelap apabila berada dibalik bayangan karena disisi }\end{array}$ \\
\hline 2 & $\begin{array}{l}\text { Hutan } \\
\text { berkerapatan } \\
\text { rendah }\end{array}$ & $\begin{array}{l}\text { Hutan dengan kerapatan antar pohon rendah atau jarang. Diinterpretasikan berwarna hijau dengan tekstur agak halus dan pola } \\
\text { berkelompok. Letaknya lebih dekat dengan pemukiman atau lahan pertanian disbanding hutan berkerapatan tinggi }\end{array}$ \\
\hline 3 & $\begin{array}{l}\text { Pemukiman } \\
\text { penduduk padat }\end{array}$ & $\begin{array}{l}\text { Pemukiman penduduk padat merupakan bangunan rumah yang diinterpretasikan berwarna putih bercampur orange dengan } \\
\text { keberkerapatan tinggi dan batas rumah antara satu dengan yang lainnya sangat berdekatan dan berasosiasi dengan jalan }\end{array}$ \\
\hline 4 & $\begin{array}{l}\text { Pemukiman } \\
\text { penduduk sedang }\end{array}$ & $\begin{array}{l}\text { Pemukiman penduduk sedang merupakan bangunan rumah yang diinterpretasikan berwarna putih bercampur oranye dengan } \\
\text { keberkerapatan sedang }\end{array}$ \\
\hline 5 & Kebun campuran & $\begin{array}{l}\text { Bentuk budidaya pertanian lahan kering dengan komoditas yang beragam (mixfarming) dan biasanya campuran antara tanaman } \\
\text { budidaya dan pohon berkayu. Kebun campuran diinterpretasi berwarna hijau tua bercampur coklat, bertekstur kasar dengan pola } \\
\text { menyebar. Tidak membentuk bentuk tertentu }\end{array}$ \\
\hline 6 & Tegalan & $\begin{array}{l}\text { Tegalan merupakan bentuk pertanian budidaya pertanian lahan kering dengan komoditas beragam dan biasanya dominan } \\
\text { tanaman palawija pada satu petak laha. Tegalan diinterpretasi berwarna coklat bercampur hijau, dengan bentuk persegi panjang, } \\
\text { bertekstur agak halus dan pola berkelompok }\end{array}$ \\
\hline 7 & Lahan Terbuka & $\begin{array}{l}\text { Lahan terbuka merupakan lahan tanpa penutup vegetasi. Lahan terbuka diinterpretasi berwarna coklat hingga krem dengan } \\
\text { bentuk persegi. Lahan terbuka merupakan lahan tanpa penutup vegetasi }\end{array}$ \\
\hline 8 & Semak belukar & $\begin{array}{l}\text { Semak merupakan lahan yang ditumbuhi rumput maupun alang-alang dengan kerapatan jarang. Semak diinterpretasi berwarna } \\
\text { hijau kecoklatan dengan pola menyebar dan bertekstur agak kasar. Letaknya umumnya dekat hutan dan jauh dari jalan utama }\end{array}$ \\
\hline 9 & Emplasmen & $\begin{array}{l}\text { Emplasmen merupakan bangunan untuk kepentingan komersil dan selain perumahan berupa pabrik, lapangan tenis dan lahan } \\
\text { terbuka seperti lapangan }\end{array}$ \\
\hline 10 & Badan air & $\begin{array}{l}\text { Badan air dalam bentuk alami maupun buatan seperti waduk, danau yang diinterpretasikan dengan tekstur halus dan berwarna } \\
\text { biru tua, dan abu-abu }\end{array}$ \\
\hline 11 & Empang & Aktivitas untuk perikanan yang tampak dengan pola pematang dan digenangi dengan air, komoditas didalamnya berupa ikan \\
\hline
\end{tabular}

Data spasial setiap parameter, kemudian ditumpangtindihkan (overlay) dengan menggunakan software ArcGIS 10.3 melalui teknik intersect dan union. Selanjutnya, menjumlahkan skor tiap parameter, sehingga diperoleh jumlah skor. Prioritas pengembangan lahan untuk kawasan wisata didasarkan pada jumlah skor terbesar. Jumlah skor dikategorikan kedalam empat prioritas pengembangan kawasan pariwisata, yaitu prioritas I, prioritas II, prioritas III, dan prioritas IV. Perhitungan tingkat perkembangan pembangunan kawasan wisata (TPPkw) menggunakan rumus berikut:

$\mathrm{TPPkw}=\sum$ skor $($ kebijakan $\{\mathrm{PR}, \mathrm{RT}, \mathrm{PB}, \mathrm{BP}, \mathrm{MH}\}+$ potensi $\{\mathrm{AR}\}+$ mitigasi bencana $\{\mathrm{LK}, \mathrm{RT}\}+$ eksisting $\{\mathrm{TL}, \mathrm{LR}\})$ 
Dimana: TPPkw: prioritas lahan untuk pengembangan kawasan wisata; PR: pola ruang; RT: persil tanah; BP: status tanah; MH: status kawasan hutan; AR: arahan lahan;
LK: lahan kritis; RT: rawan tsunami; TL: tutupan lahan; LR: kemiringan lereng.

Tabel 2. Parameter tingkat perkembangan pembangunan kawasan wisata pantai

\begin{tabular}{|c|c|c|c|c|}
\hline No & Jenis Data & Parameter (Kode) & Skor & Sumber \\
\hline \multirow[t]{16}{*}{1} & Kebijakan & a. $\quad$ Pola Ruang (PR) Skala 1:50.000 & & \multirow{5}{*}{ Bappeda Kab Bulukumba } \\
\hline & & Kawasan Perikanan & 3 & \\
\hline & & Kawasan Perlindungan di Bawahnya & 0 & \\
\hline & & Kawasan Pemukiman & 1 & \\
\hline & & Kawasan Pertanian & 2 & \\
\hline & & b. $\quad$ Persil Tanah (PB) Skala 1: 10.000 & & \multirow{4}{*}{ Dinas Pertanahan, Kab Bulukumba } \\
\hline & & Hak Milik & 0 & \\
\hline & & Hak Pakai & 1 & \\
\hline & & Tidak ada data & 2 & \\
\hline & & c. $\quad$ Status Tanah (BP) Skala 1: 50.000 & & \multirow{4}{*}{ Dinas Pertanahan, Kab Bulukumba } \\
\hline & & Suaka Margasatwa & 1 & \\
\hline & & Tanah Hak UUPA, perorangan & 2 & \\
\hline & & Tanah Negara Bukan Untuk Kepentingan Umum & 0 & \\
\hline & & d. $\quad$ Status Kawasan Hutan (MH) Skala 1: 50.000 & & \multirow{3}{*}{ KLHK } \\
\hline & & Areal Penggunaan Lain & 2 & \\
\hline & & Taman Hutan Rakyat & 1 & \\
\hline \multirow[t]{4}{*}{2} & Potensi & e. Arahan Lahan (AR) Skala 1: 50.000 & & \multirow{4}{*}{ BBSDLP } \\
\hline & & Lahan Basah (LB) & 2 & \\
\hline & & Tanaman Pertanian (TP) & 1 & \\
\hline & & Pulau (X3) & 3 & \\
\hline \multirow[t]{6}{*}{3} & Mitigasi Bencana & f. Lahan Kritis (LK) Skala 1: 50.000 & & \multirow{3}{*}{ Bappeda Kab Bulukumba } \\
\hline & & Kritis (K) & 0 & \\
\hline & & Tidak Kritis (TK) & 1 & \\
\hline & & g. $\quad$ Rawan Tsunami (RT) Skala 1:50.000 & & \multirow{3}{*}{ Bappeda Kab Bulukumba } \\
\hline & & Rawan tsunami & 0 & \\
\hline & & Tidak rawan tsunami & 1 & \\
\hline \multirow[t]{14}{*}{4} & Eksisting & h. Tutupan Lahan (TL) Skala 1:10.000 & & \multirow{11}{*}{ Hasil Analisis } \\
\hline & & Badan Air & 0 & \\
\hline & & Hutan Berkerapatan Tinggi & 1 & \\
\hline & & Hutan Berkerapatan Rendah & 1 & \\
\hline & & Kebun Campuran & 2 & \\
\hline & & Lahan Terbuka & 3 & \\
\hline & & Emplasmen & 0 & \\
\hline & & Pemukiman Kerapatan Padat & 0 & \\
\hline & & Pemukiman Kerapatan Sedang & 0 & \\
\hline & & Semak Belukar & 3 & \\
\hline & & Tegalan & 2 & \\
\hline & & i. $\quad$ Kemiringan Lereng (LR) Skala 1:50.000 & & \multirow{3}{*}{ DEMNAS/BIG } \\
\hline & & $0-2$ & 1 & \\
\hline & & $2-5$ & 0 & \\
\hline
\end{tabular}

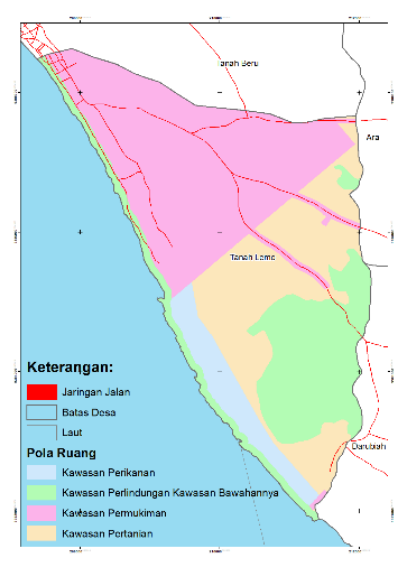

a

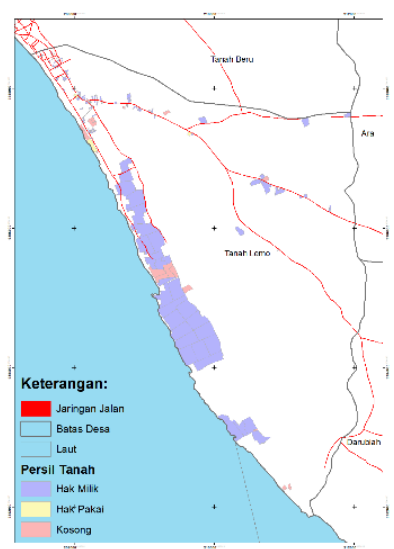

b

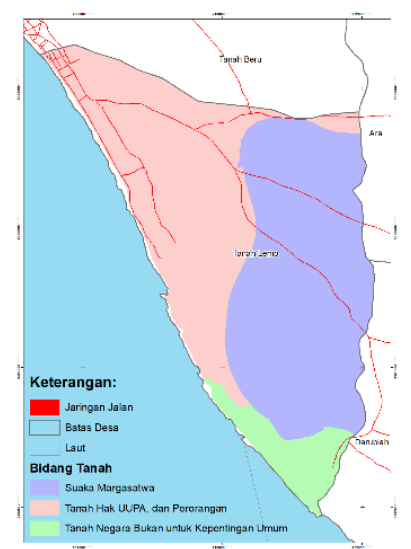

$\mathrm{c}$

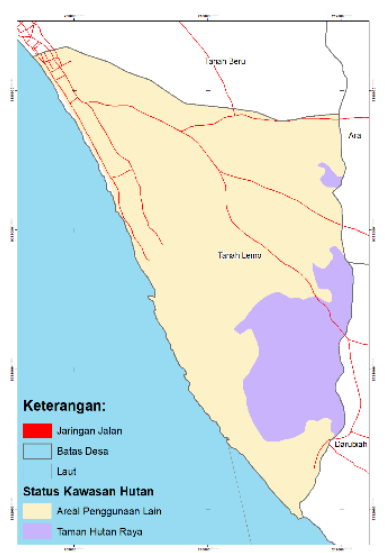

d 


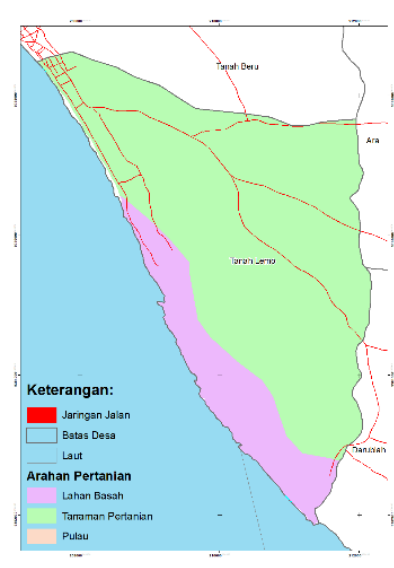

$\mathrm{E}$

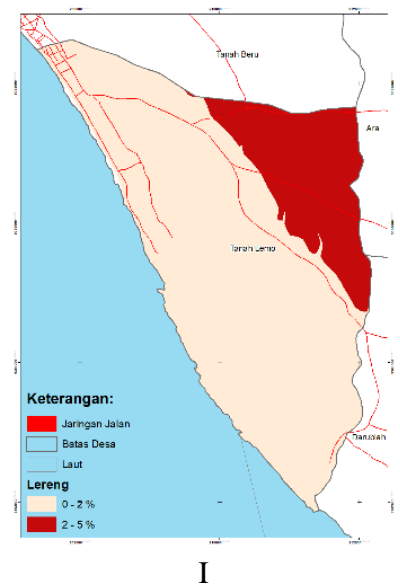

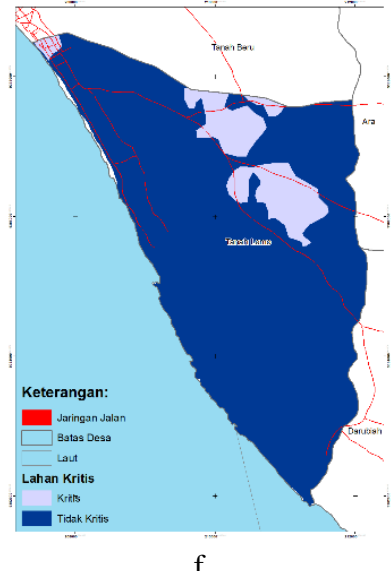

$\mathrm{f}$

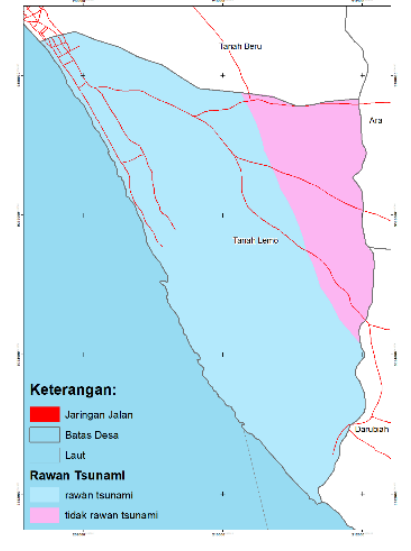

G

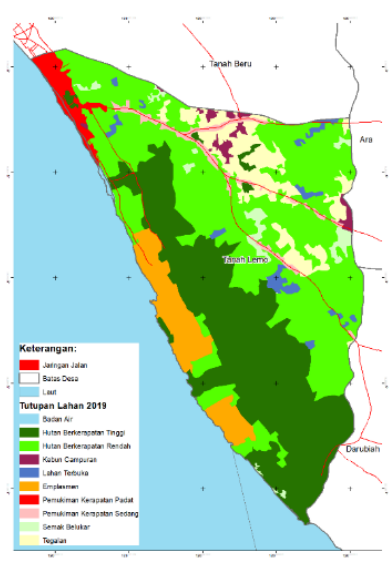

$\mathrm{h}$

Gambar 2. Peta Tiap Parameter Penentuan Kawasan Wisata, a). pola ruang, b). persil tanah, c). bidang tanah, d). status kawasan hutan, e). arahan pertanian, f). lahan kritis, g). rawan tsunami, h). penggunaan lahan, i). lereng.

\section{Analisis Strength Weaknesses Opportunities Threats (SWOT)}

Analisis SWOT adalah identifikasi berbagai faktor secara sistematis untuk merumuskan strategi. Analisis ini didasarkan pada logika yang dapat memaksimalkan kekuatan (strengths/S) dan peluang (opportunities/O), namun secara bersamaan dapat meminimalkan kelemahan (weaknesses/W) dan ancaman (threats/T). Penggunan analisis SWOT dalam penelitian ini digunakan dalam menyusun formulasi strategis dengan menggabungkan berbagai indikator yang terdapat dalam kekuatan, kelemahan, peluang, dan ancaman kawasan Pantai LemoLemo. Dalam perencanaan pariwisata selain melalui pendekatan teknokratis (birokrat), juga perlu mengedepankan perencanaan partisipatif, salah satunya dengan analisis SWOT ini (kualitatif). Perencanaan pariwisata harus lebih peka terhadap penduduk dan tradisi, dan lebih berorientasi adat / endogen (Liu et al., 2006; Chiappa, et al., 2018). Model penggabungannya menggunakan matriks SWOT (Rangkuti 2011).

\section{HASIL DAN PEMBAHASAN}

\section{Identifikasi Penggunaan Lahan Desa Tanah Lemo Tahun 2019}

Berdasarkan hasil interpretasi citra google earth diperoleh 11 jenis tutupan lahan, yaitu badan air, emplasmen, hutan berkerapatan tinggi, hutan berkerapatan rendah, kebun campuran, lahan terbuka, pemukiman kerapatan padat, pemukiman kerapatan sedang, semak belukar dan tegalan. Selanjutnya, dilakukan verifikasi lapang sebanyak 16 titik tutupan lahan. Beberapa tutupan lahan di lokasi studi sesuai disajikan pada Gambar 2. Berdasarkan 16 titik tersebut ditemukan 11 titik tutupan lahan yang sesuai dengan interpretasi sebelumnya dan 5 titik tidak sesuai, sehingga perlu dilakukan revisi tutupan lahan. Berdasarkan verifikasi lapang, diperoleh peta penggunaan lahan Desa Tanah Lemo tahun 2019. Penggunaan lahan terluas adalah tegalan dengan luas 1411 ha $(48.73 \%)$. Penggunaan lahan terkecil adalah badan air dengan luas 0.6 ha $(0.02 \%)$. Sebaran jenis dan luas penggunaan lahan Desa Tanah Lemo Tahun 2019 selengkapnya sesuai disajikan pada Tabel 4 dan Gambar 3.

Tabel 4. Luas masing-masing penggunaan lahan di lokasi studi

\begin{tabular}{rlrr}
\hline \multirow{2}{*}{ No } & \multicolumn{2}{|}{ Tutupan Lahan } & \multicolumn{2}{c}{ Luas } \\
\cline { 3 - 4 } & & \multicolumn{1}{c}{ ha } & \multicolumn{1}{c}{ \% } \\
\hline 1 & Badan Air & 0.6 & 0.02 \\
2 & Emplasmen & 107.3 & 3.71 \\
3 & Hutan Berkerapatan Rendah & 699.0 & 24.14 \\
4 & Hutan Berkerapatan Tinggi & 529.1 & 18.27 \\
5 & Kebun Campuran & 18.3 & 0.63 \\
6 & Lahan Terbuka & 28.3 & 0.98 \\
7 & Pemukiman Kerapatan Padat & 33.5 & 1.16 \\
8 & Pemukiman Kerapatan Sedang & 34.7 & 1.20 \\
9 & Semak Belukar & 29.6 & 1.02 \\
10 & Tegalan & $1,411.1$ & 48.73 \\
11 & (blank) & 4.1 & 0.14 \\
\hline & Total & $\mathbf{2 , 8 9 5 . 5}$ & $\mathbf{1 0 0 . 0 0}$ \\
\hline
\end{tabular}




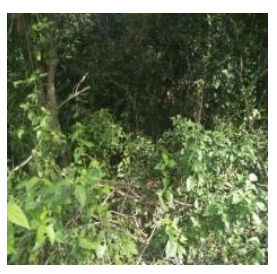

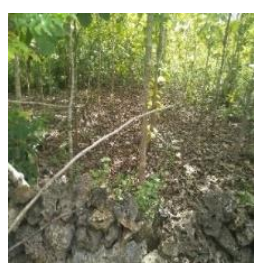

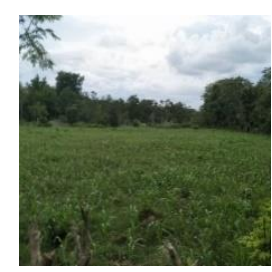

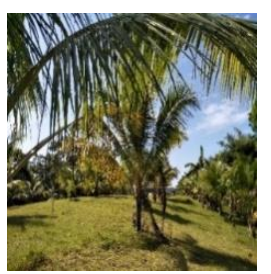

d

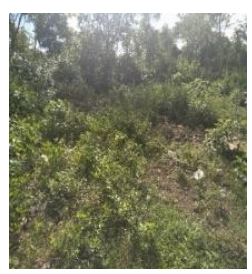

Gambar 3. Pengamatan lapang beberapa penggunaan lahan di Desa Tanah Lemo (a) hutan berkerapatan tinggi, (b) hutan berkerapatan rendah, (c) tegalan, (d) kebun campuran, (e) semak belukar

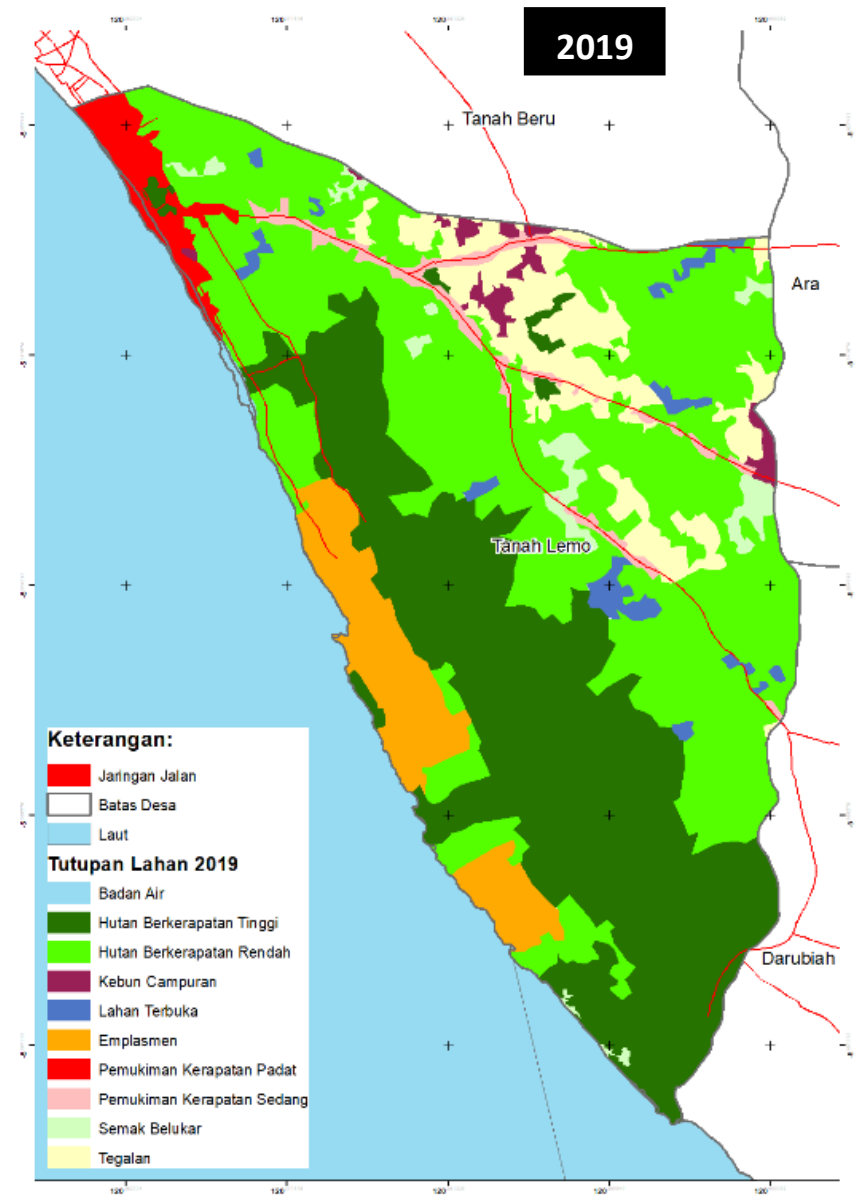

Gambar 4. Penggunaan lahan eksisting di Desa Tanah Lemo tahun 2019

\section{Land rent Tiap Penggunaan Lahan di Desa Tanah Lemo}

Land rent dapat menunjukkan tingkat ekonomi lahan pada penggunaan tertentu. Nilai land rent penggunaan tertentu yang tinggi menunjukkan penggunaan lahan tersebut memiliki keuntungan secara ekonomi yang tingga pula. Dengan demikian, nilai land rent dapat menjadi alat yang mampu memahami nilai tanah (land markets), kebijakan, dan regulasi di wilayah tersebut (Jager, 2020).

Berdasarkan hasil analisis land rent (tabulasi), dengan responden sejumlah 11 orang diperoleh nilai land rent tertinggi adalah pemukiman penduduk padat (Rp. $150.458 / \mathrm{m}^{2} /$ tahun) dan terkecil adalah lahan terbuka, yaitu sebesar Rp. 3.538/ $\mathrm{m}^{2} /$ tahun. Umumnya memang lahan terbangun memiliki nilai land rent lebih besar dibandingkan pertanian, yaitu land rent permukiman rata-rata Rp. 474. 095/ $/ \mathrm{m}^{2} /$ tahun dan pertanian sebesar Rp. $7.520 / \mathrm{m}^{2} /$ tahun (Mulya et al., 2019). Perbandingan nilai land rent pertanian dan non permukiman di lokasi studi menunjukkan perbandingan 1:2, artinya nilai ekonomi lahan permukiman 2 kali lipat dibandingkan lahan yang pertanian. Nilai land rent inilah yang menjadi salah satu penyebab terjadinya alih fungsi lahan. Lebih lanjut dapat diperbandingkan nilai land rent penggunaan lahan yang sama di Jawa dan Luar Jawa juga menunjukkan hasil yang berbeda. Dalam penelitian ini, nilai land rent dapat membantu menentukan dan memberikan informasi dalam penentuan skor penggunaan lahan untuk menentukan prioritas lahan untuk pengembangan wisata di Desa Tanah Lemo. Penggunaan lahan yang memiliki land rent yang lebih besar (seperti permukiman) dibandingkan land rent hutan atau tanaman pertanian. Dengan demikian apabila Pemerintah Daerah akan mengusahakan lahan ini memerlukan biaya yang besar untuk ganti rugi atau sejenisnya. Oleh karena itu, pemberian skor pada parameter permukiman diberi skor " 0 " (prioritas rendah). Alternatif lainnya, tentunya merencanakan sebagai kawasan wisata dengan penguasaan mandiri oleh masyarakat dengan menyesuaikan bentuk wisata yang ditawarkan, misalnya direncanakan untuk tempat menginap 
sementara/homestay pada penggunaan lahan permukiman. Pada penggunaan lahan hutan, tentunya diarahkan pada pariwisata yang tidak merubah vegetasi hutan, seperti taman hutan rakyat atau sejenisnya. Sementara itu, pada penggunaan lahan pertanian, semak, dan lahan terbuka lebih leluasa dalam merencanakannya dibandingkan penggunaan lahan lainnya, karena pemanfaatannya saat ini lebih mudah disesuaikan dengan rencana wisata yang akan dikembangkan.

\section{Penentuan Prioritas Lahan untuk Pengembangan Kawasan Wisata}

Pariwisata merupakan salah satu sektor utama di Kabupaten Bulukumba. Sektor pariwisata yang sesuai dengan potensi lokal di Desa Tanah Lemo adalah pariwisata pantai. Terdapat banyak pantai yang indah di wilayah Kabupaten Bulukumba, namun salah satu pantai yang belum dikembangkan adalah Pantai Lemo-Lemo. Pantai ini berlokasi di Desa Tanah Lemo, Kecamatan Bontobahari. Potensi pantai di lokasi studi adalah pasir putih dan air laut yang masih jernih, dan gugusan batu karang yang menyembul ke permukaan air (Agustina et al., 2018) (Gambar 5) serta tempat pembuatan miniatur Kapal Phinisi (Baharuddin et al., 2019). Pantai Lemo-Lemo belum berkembang jika dibandingkan dengan Pantai Pasir Putih Bira dan Pantai Samboang, karena aksesnya masih terbatas dibandingkan pantai lainnya (Gambar 7b).
Penentuan prioritas lahan untuk pengembangan kawasan wisata merupakan salah satu tahapan perencanaan yang dapat digunakan untuk menentukan lahan-lahan yang dapat dikembangkan menjadi kawasan wisata. Terdapat 4 (empat) kriteria umum dalam menentukan prirotas lahan, yaitu kebijakan, potensi, mitigasi bencana dan kondisi eksisting. Masing-masing kriteria umum disusun berdasarkan kriteria spesifik sesuai disajikan pada Tabel 2.

Prioritas pengembangan lahan untuk kawasan wisata di Desa Tanah Lemo disusun berdasarkan jumlah skor terbesar. Semakin besar skor menunjukkan semakin prioritas lahan tersebut untuk dikembangkan sebagai kawasan wisata. Berdasarkan kriteria, jumlah maksimum skor adalah 18, sedangkan minimumnya adalah 0 . Berdasarkan analisis diperoleh skor antara 0-14. Setelah dilakukan crosscheck data, pada skor 0-6 terdistribusi pada satu lokasi yang sama, dan diperoleh informasi bahwa areal tersebut terdapat data yang tidak lengkap, sehingga dalam penyajiannya pada penelitian ini skor 0-6 dinyatakan data tidak lengkap (tidak direkomendasikan). Dengan demikian, jumlah skor yang direkomendasikan untuk menentukan prioritas lahan untuk kawasan wisata antara 7-14. Semakin besar jumlah skor, semakin diprioritaskan.

Berdasarkan tingkat prioritas pengembangan lahan di Desa Tanah Lemo, lahan dengan priortitas 1 seluas 49 ha atau $1.7 \%$, prioritas II seluas 766.1 ha atau $26.5 \%$, prioritas III seluas 1.571 ha atau 54\%, dan prioritas IV seluas 492 ha atau $17 \%$. Tabulasi dan distribusi spasial lahan berdasarkan prioritasnya sesuai disajikan pada Tabel 6 dan Gambar 6 .

Tabel 5. Land rent di masing-masing penggunaan lahan di lokasi studi

\begin{tabular}{|c|c|c|c|c|}
\hline No & Penggunaan Lahan & Kode Vg-NVg & Kode Pt-Pmk & Land rent $\left(\mathrm{Rp} / \mathrm{m}^{2} / \mathrm{tahun}\right)$ \\
\hline 1 & Badan Air & - & - & 9,719 \\
\hline 2 & Empang & - & - & 4,600 \\
\hline 3 & Hutan Kerapatan Tinggi & $\mathrm{Vg}$ & - & 5,625 \\
\hline 4 & Hutan Kerapatan Rendah & $\mathrm{Vg}$ & - & 3,475 \\
\hline 5 & Pemukiman Penduduk Padat & $\mathrm{NVg}$ & Pmk & 150,458 \\
\hline 6 & Pemukiman Penduduk Sedang & $\mathrm{NVg}$ & Pmk & 118,175 \\
\hline 7 & Tegalan & $\mathrm{Vg}$ & $\mathrm{Pt}$ & 34,600 \\
\hline 8 & Kebun Campuran & $\mathrm{Vg}$ & $\mathrm{Pt}$ & 96,934 \\
\hline 9 & Semak Belukar & $\mathrm{Vg}$ & - & 5,906 \\
\hline 10 & Lahan Terbuka & $\mathrm{NVg}$ & - & 3,538 \\
\hline 11 & Emplasmen & $\mathrm{NVg}$ & - & 12,500 \\
\hline & $\begin{array}{l}\text { Keterangan: LR = land rent; ju } \\
\text { Perbandingan Land Rent: } \\
\text { Vegetasi }(\mathrm{Vg}): \text { Non Vegetasi } \\
\text { Pertanian }(\mathrm{Pt}): \text { Permukiman }(\mathrm{P}\end{array}$ & lah responden 11 & orang & $\begin{array}{c}1: 2.4 \\
1: 2\end{array}$ \\
\hline
\end{tabular}
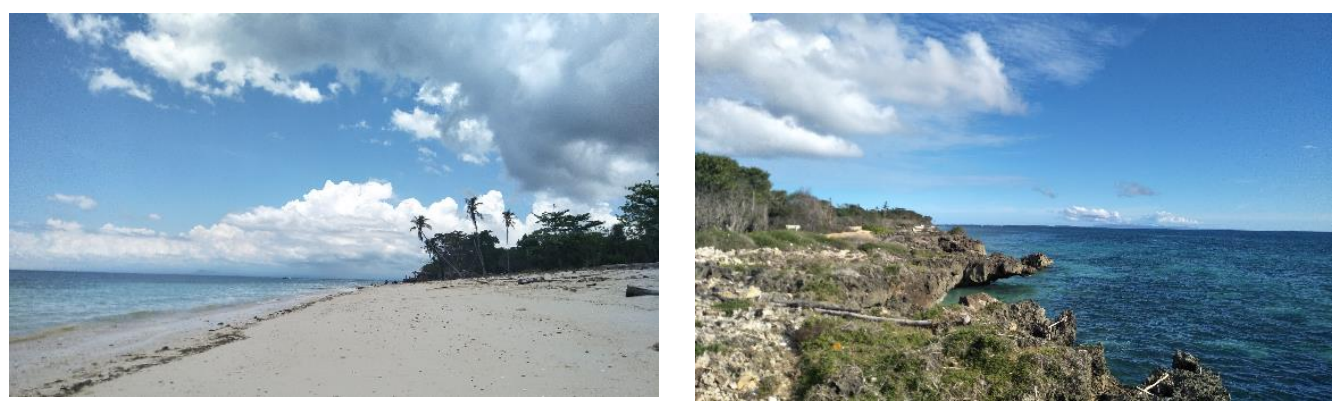

Gambar 5. Keindahan Pantai Lemo-Lemo difoto dari dua titik lokasi (pasir putih dan karang) 
Tabel 6. Tingkat prioritas lahan untuk pengembangan kawasan wisata

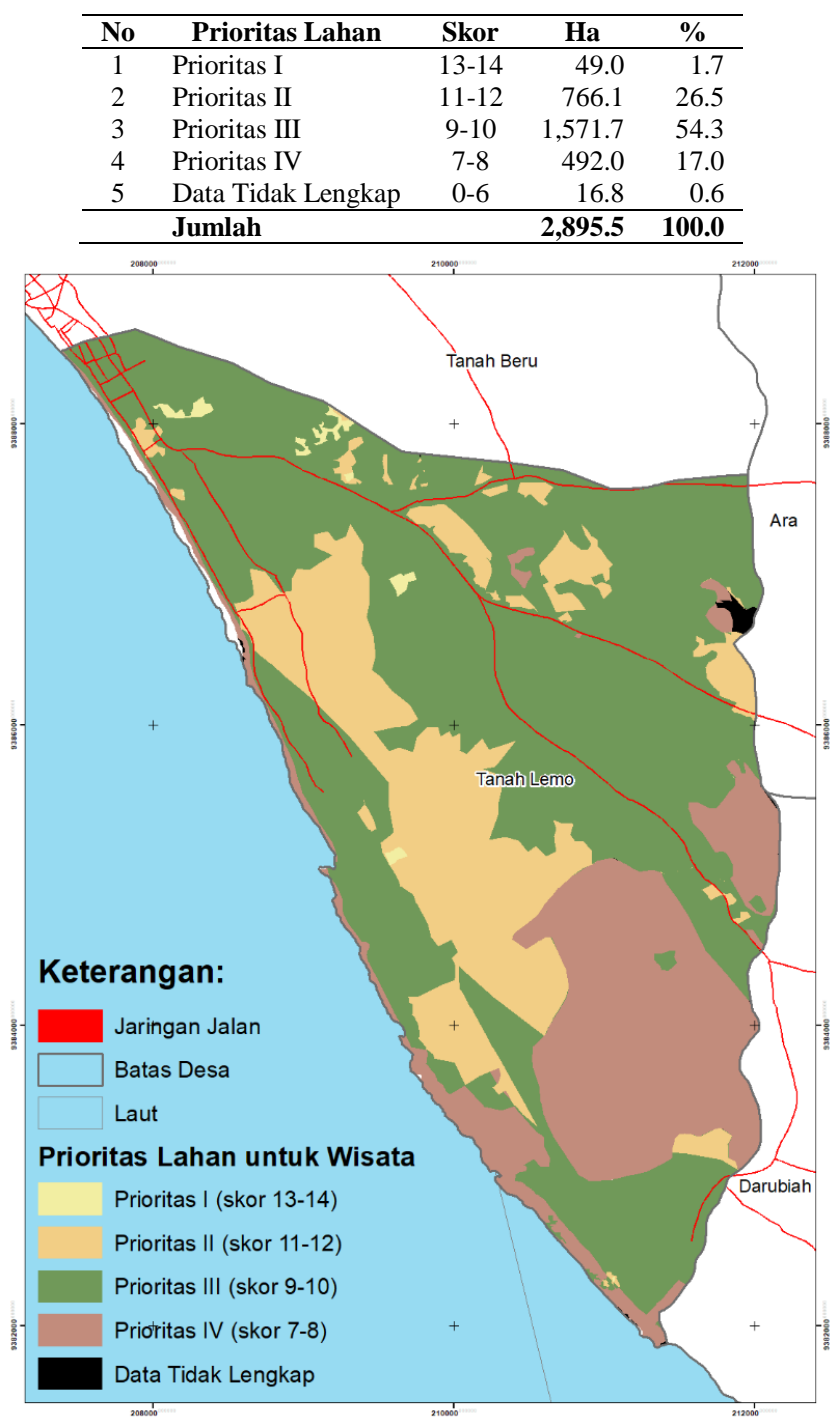

Gambar 6. Peta prioritas lahan untuk pengembangan wisata di Desa Tanah Lemo

\section{Strategi Pengembangan Kawasan Wisata}

Salah satu destinasi wisata unggulan di lokasi studi adalah Pantai Lemo-Lemo. Sehubungan dengan masih kalah bersaingnya Pantai Lemo-Lemo dengan pantai lainnya (seperti Pantai Bira dan lain sebagainya), maka perlu dilakukan analisis SWOT dalam rangka penentuan strategi pengembangan pantai kedepan. Data peluang, ancaman, kekuatan dan kelemahan diperoleh dari hasil wawancara terhadap responden, baik dari unsur Pemerintah Daerah (Kepala Dinas dan Sekretaris Dinas Pariwisata Kabupaten Bulukumba), dan wisatawan lokal. Rumusan strategi pengembangan wisata Pantai Lemo-Lemo berdasarkan hasil analisis SWOT sesuai disajikan pada Tabel 7.

Hasil dari interaksi faktor strategi internal dengan eksternal menghasilkan alternatif-alternatif strategi. Strategi SO (Strengths-Opportunities) merupakan strategi yang dibuat dengan memanfaatkan seluruh kekuatan untuk merebut dan memanfaatkan peluang sebesar-besarnya. Strategi ST (Strengths-Threats) merupakan strategi yang dibuat dengan menggunakan kekuatan yang dimiliki untuk mengatasi ancaman. Strategi WO (WeaknessesOpportunities) merupakan strategi yang dibuat berdasarkan pemanfaatan peluang yang ada dengan meminimalkan kelemahan yang ada. Strategi WT (Weaknesses-Threats) merupakan strategi yang digunakan untuk mengurangi kelemahan dalam rangka meminimalisir/menghindari ancaman. Rumusan strategi pengembangan wisata dirumuskan dengan menggunakan matriks strategi hasil analisis SWOT.

Berdasarkan analisis pendekatan SWOT, kawasan Pantai Lemo-Lemo mempunyai kekuatan yang dapat dijadikan sebagai potensi wisata. Faktor kekuatannya meliputi obyek wisata alam, pantai bersih dan garis pantai strategis sehingga strategis untuk wisata pantai serta memiliki modal dasar kawasan wisata pantai, yaitu sumber mata air, goa (Gambar 7d), taman hutan rakyat dan situs budaya. Daerah kawasan Pantai Lemo merupakan daerah kerajaan Bontobahari pada jaman dahulu, sekitar kawasan wisata pantai masih terdapat beberapa batuan yang dipercayai masyarakat sebagai puing-puing istana. Pantai Lemo-Lemo juga mempunyai kelemahan yang dapat menghambat pengembangan wisata di kawasan tersebut, diantaranya adalah aksesbilitas dan infrastruktur sekitar kawasan masih sangat terbatas, jalan sekitar kawasan masih sempit (Gambar 7a dan 7b) dan beberapa bagian berlubang. Selain itu pemahaman masyarakat mengenai pengelolaan pariwisata masih rendah serta kawasan sekitar pantai masih belum tertata rapih (Gambar7c).

Faktor eksternal yang terdiri dari peluang dan ancaman juga berpengaruh dalam pengembangan wisata. Minat terhadap pariwisata lokal terutama wisata pantai semakin meningkat dan Pantai Lemo-Lemo termasuk dalam salah satu daerah pengembangan kawasan pariwisata berdasarkan Peraturan Daerah Kabupaten Bulukumba Nomor 6 Tahun 2009 tentang Rencana Induk Pengembangan Kepariwisataan Daerah (RIPDA) Kabupaten Bulukumba. Namun, adanya saingan wisata pantai lainnya dan lembaga adat yang menyangsikan keberadaan pariwisata Pantai Lemo-Lemo dapat merusak situs budaya dapat menjadi ancaman dalam pengembangan kawasan wisata pantai.

Berdasarkan hasil analisis SWOT terdapat 10 strategi pengembangan kawasan wisata Pantai Lemo-Lemo yaitu (1) Meningkatkan potensi daya tarik wisata dengan promosi wisata atau menjadi tuan rumah kegiatan festival wisata lokal atau nasional (S1 \& O1,2), (2) Meningkatkan potensi daya tarik wisata dengan mengembangkan wisata mata air, taman hutan rakyat dan situs budaya (S2 \& O2), (3) Mengembangkan alternatif wisata lainnya, misalnya taman bermain dengan adanya dukungan kebijakan pemerintah (S3 \& O2), (4) Mengadakan pelatihan / pembinaan mengenai wisata pantai secara terpadu (W1 \& O1), (5) Membangun aksesibilitas dan infrastruktur sekitar kawasan wisata pantai (W2 \& O2), (6) Membangun tempat pariwisata pantai yang menarik, lengkap dan inovatif sesuai minat wisatawan (W3 \& O2), (7) Mengadakan sosialisasi terhadap lembaga adat mengenai pengembangan kawasan wisata Pantai Lemo-Lemo yang terintegrasi (aspek alam, estetika/asri, budaya, sejarah dan religi) (S1,2,3 \& T1), (8) Mengembangkan daya saing potensi wisata alam dan unsur budaya yang tidak ada di wisata lokal lainnya (S1,2,3 \& T2), Meningkatkan SDM mengenai pariwisata dengan 
mengadakan pelatihan/pembinaan dan studi banding (W1 \& T1), (10) Meningkatkan daya saing wisata dengan memperbaiki aksesibilitas, membangun infrastruktur serta melakukan penataan ruang yang terintegrasi (W2,3 \& T2).

Tabel 7. Matriks Strategi Hasil Analisis SWOT

\begin{tabular}{|c|c|c|}
\hline Eksternal & $\begin{array}{l}\text { Kekuatan (Strengths) } \\
\text { 1. Obyek wisata alam } \\
\text { 2. Pantai bersih dan garis pantai memanjang, strategis } \\
\text { untuk wisata pantai } \\
\text { 3. } \begin{array}{l}\text { Memiliki modal dasar kawasan pariwisata. } \\
\text { (pantai,sumber mata air, taman hutan rakyat dan } \\
\text { situs budaya) }\end{array}\end{array}$ & $\begin{array}{l}\text { Kelemahan (Weaknesses) } \\
\text { 1. Tingkat pemahaman pengelolaan } \\
\text { kepariwisataan masyarakat masih rendah } \\
\text { 2. Aksesibilitas dan infrastruktur penunjang } \\
\text { terbatas } \\
\text { 3. Minimnya penataan tempat wisata }\end{array}$ \\
\hline $\begin{array}{l}\text { Peluang (Opportunities) } \\
\text { 1. } \begin{array}{l}\text { Adanya PERDA yang telah } \\
\text { dibuat No.6 Tahun } 2009 \text { tentang }\end{array} \\
\text { RIPDA } \\
\text { 2. } \begin{array}{l}\text { Pariwisata lokal meningkat dan } \\
\text { tingginya minat wisata pantai }\end{array}\end{array}$ & $\begin{array}{l}\text { SO STRATEGY } \\
\text { 1. Meningkatkan potensi daya tarik wisata dengan } \\
\text { promosi wisata atau menjadi tuan rumah kegiatan } \\
\text { festival wisata lokal atau nasional }\left(\mathrm{S}_{1} \& \mathrm{O}_{1,2}\right) \\
\text { 2. Meningkatkan potensi daya tarik wisata dengan } \\
\text { mengembangkan wisata mata air, taman hutan } \\
\text { rakyat dan situs budaya }\left(\mathrm{S}_{2} \& \mathrm{O}_{2}\right) \\
\text { 3. } \\
\text { Mengembangkan alternatif wisata lainnya, misalnya } \\
\text { taman bermain dengan adanya dukungan kebijakan } \\
\text { pemerintah }\left(\mathrm{S}_{3} \& \mathrm{O}_{2}\right)\end{array}$ & $\begin{array}{l}\text { WO STRATEGY } \\
\text { 1. } \begin{array}{l}\text { Mengadakan pelatihan / pembinaan mengenai } \\
\text { wisata pantai secara terpadu }\left(\mathrm{W}_{1} \& \mathrm{O}_{1}\right)\end{array} \\
\text { 2. } \begin{array}{l}\text { Membangun aksesibilitas dan infrastruktur } \\
\text { sekitar kawasan wisata pantai }\left(\mathrm{W}_{2} \& \mathrm{O}_{2}\right)\end{array} \\
\text { 3. } \\
\begin{array}{l}\text { Membangun tempat pariwisata pantai yang } \\
\text { menarik, lengkap dan inovatif sesuai minat } \\
\text { wisatawan }\left(\mathrm{W}_{3} \& \mathrm{O}_{2}\right)\end{array}\end{array}$ \\
\hline $\begin{array}{l}\text { Ancaman (Threats) } \\
\text { 1. } \begin{array}{l}\text { Adanya lembaga adat yang } \\
\text { menyangsikan keberadaan } \\
\text { pariwisata pantai Lemo-Lemo } \\
\text { dapat merusak situs budaya }\end{array} \\
\text { 2. } \quad \begin{array}{l}\text { Saingan wisata lokal lainnya } \\
\text { (Pantai Bira) }\end{array}\end{array}$ & 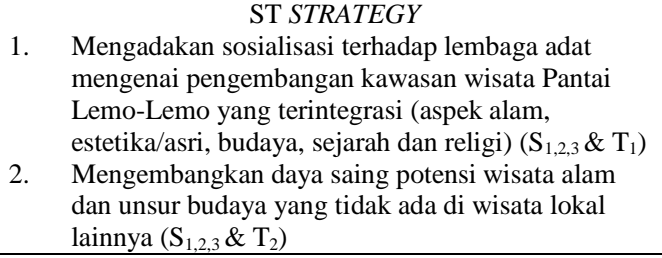 & \begin{tabular}{ll}
\multicolumn{1}{c}{ WT STRATEGY } \\
1. \\
Meningkatkan SDM mengenai pariwisata \\
dengan mengadakan pelatihan/pembinaan dan \\
studi banding $\left(\mathrm{W}_{1} \& \mathrm{~T}_{1}\right)$ \\
2. \\
Meningkatkan daya saing wisata dengan \\
memperbaiki aksesibilitas, membangun \\
infrastruktur serta melakukan penataan ruang \\
yang terintegrasi $\left(\mathrm{W}_{2,3} \& \mathrm{~T}_{2}\right)$
\end{tabular} \\
\hline
\end{tabular}
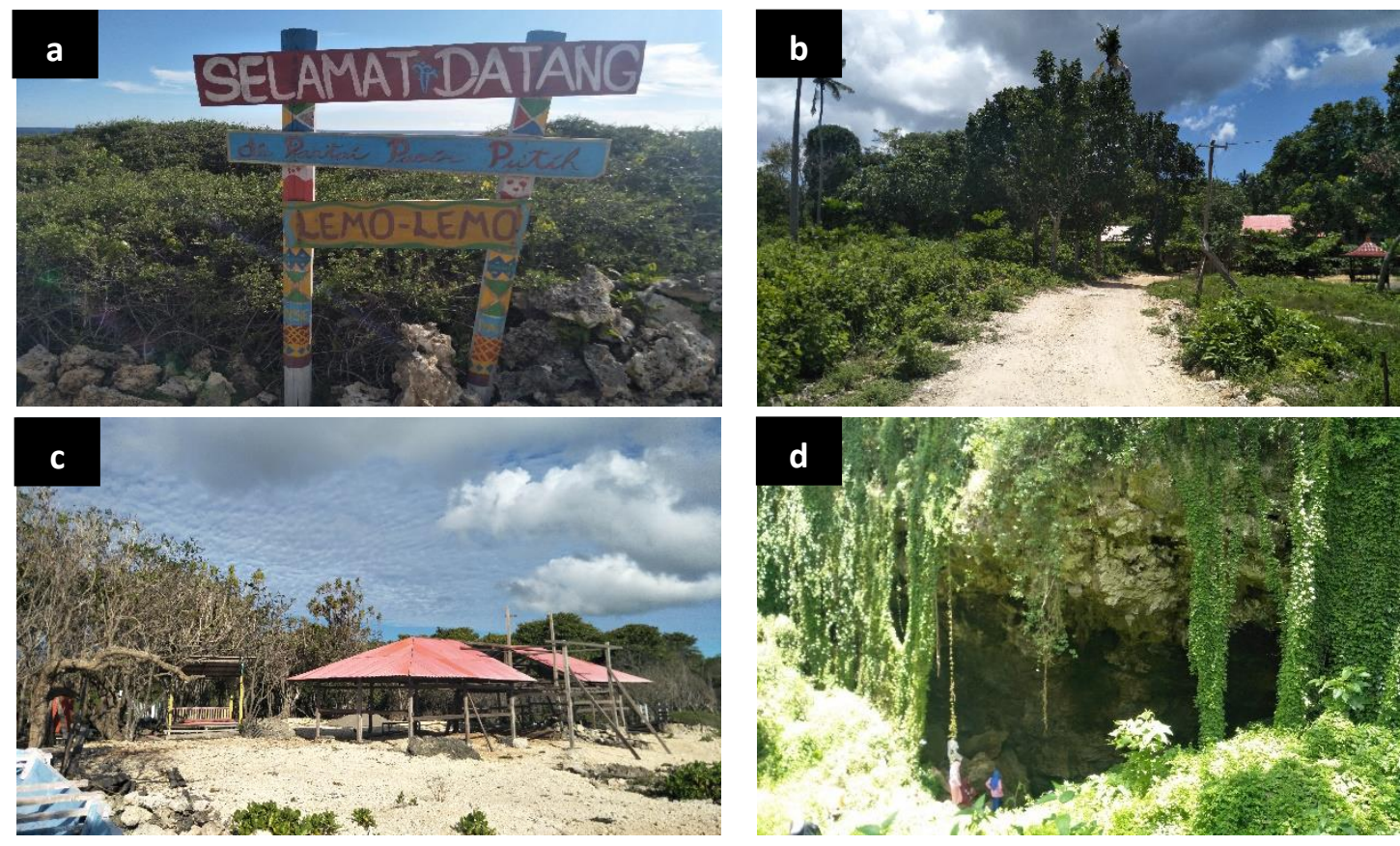

Gambar 7. a). Signage pantai masih minim, b). jalan menuju pantai, c). bangunan di pinggir pantai yang tidak tertata, d). gua di dekat pantai

\section{SIMPULAN DAN SARAN}

\section{Simpulan}

Berdasarkan uraian pada hasil penelitian dapat ditarik empat simpulan sebagai berikut:

1. Jenis penggunaan lahan di Desa Tanah Lemo terdiri dari 11 jenis penggunaan lahan dengan penggunaan lahan terluas adalah tegalan seluas 1411 ha (48.73\%). Tegalan memiliki luasan terluas menunjukkan potensi/tersedianya lahan untuk pengembangan kawasan wisata di wilayah ini kedepan.
2. Nilai land rent permukiman memiliki nilai terbesar dibandingkan penggunaan lahan lainnya (>Rp. $100.000 / \mathrm{m}^{2} /$ tahun). Ini menunjukkan bahwa perlu strategi yang tepat dan investasi yang besar apabila ingin memanfaatkan lahan ini untuk pengembangan kawasan wisata (pembebasan lahan).

3. Secara umum, tersebar lahan di Desa Tanah Lemo yang memiliki potensi untuk pengembangan kawasan wisata, khususnya diprioritaskan pada lahan seluas 49 ha (prioritas 1) terlebih dahulu.

4. Objek wisata yang paling strategis dan potensial di wilayah studi adalah Pantai Lemo-Lemo. Strategi 
pengembangan Kawasan wisata Pantai Lemo-Lemo yaitu promosi wisata atau menjadi tuan rumah kegiatan festival wisata lokal maupun nasional, pengembangan wisata mata air, taman hutan air, dan situs budaya yang tidak ada di wisata lokal lainnya, pengembangan alternatif wisata lainnya yang menarik, lengkap dan inovatif sesuai, memperbaiki aksesibilitas ke lokasi, membangun infrastruktur penunjang pariwisata, penataan ruang yang terintegrasi mendukung sektor wisata, serta mengadakan pelatihan/pembinaan dan studi banding mengenai pengelolaan wisata lokal (alam, estetika/asri, budaya, sejarah dan religi).

\section{Saran}

1. Informasi di lapangan menunjukkan banyaknya alih fungsi lahan di lokasi studi, khususnya vegetasi ke non vegetasi, hal ini perlu pengendalian dari pemerintah agar potensi alam yang ada tetap lestari.

2. Adanya sosialisasi pengelolaan kepariwisataan kepada masyarakat, diantaranya perbaikan sistem promosi wisata yang massif dengan memanfaatkan teknologi informasi (TI).

\section{DAFTAR PUSTAKA}

Agustina, A., M.S. Madjid dan Jumadi. 2018. Objek wisata pantai Lemo-Lemo di Kabupaten Bulukumba 20002015. J. Pattingalloang, 5(1): 111-120.

Almeida, J.C, F. Costa and N. da Silva. 2017. A framework for conflict analysis in spatial planning for tourism. Tourism Management Perpsectives, 24:94-106. https://doi.org/10.1016/j.tmp.2017.07.021

Ante, E, N.M. Benu dan V.R.B. Moniaga. 2016. Dampak ekonomi dan sosial alih fungsi lahan pertanian hortikultura menjadi kawasan wisata Bukit Rurukan di Kecamatan Tomohon Timur, Kota Tomohon. Agri-Sosio Ekonomi, 12(3):113-124.

Baharuddin, L. M.R. Bochari dan Firmansyah. 2019. Pengembangan Kawasan Tanah Lemo dan Ara sebagai Pusat Industri Kerajinan Miniatur Kapal Phinisi di Kecamatan Bontobahari, Kabupaten Bulukumba. J. Teknologi Terapan untuk Pengabdian Masyarakat, 1(2): 1-7.

Blancas, F.J, M.L. Oyola, M. Gonzales, F.M. Guerrero and R. Caballero. 2011. How to use sustainability indicators for tourism planning: The case of rural tourism in Andaluasia (Spain). Science of The Total Environment, 412-413: 28-45. https://doi.org/10.1016/j.scitotenv.2011.09.066

Chiappa, G, D.M. Atzeni and V. Ghasemi. 2018. Community-based collaborative tourism planning in islands: A cluster analysis in the context of Costa Smeralda. J. of Destination Marketing and Management, $\quad$ 8: 41-48. https://doi.org/10.1016/j.jdmm.2016.10.005

Czyżewski, B. and A. Matuszczak. 2016. A new land rent theory for sustainable agriculture. Land Use Policy,
55(2016): $222-229$.
hub.ren/10.1016/j.landusepol.2016.04.002

Jager, J. 2020. Land Rent Theory. International Encyclopedia of Human Geography (Second Edition). Pg 93-98. https://doi.org/10.1016/B978-008-102295-5.10666-3

Kantola. S, M. Uusitalo, V. Nivala and S. Tuulentie. 2018. Tourism resort users' participation in planning: Testing the public participation geographic information system method in Levi, Finnish Lapland. Tourism Management Perspectives, 27: 22-32. https://doi.org/10.1016/j.tmp.2018.04.001.

Lai, K, Y. Li and X. Feng. 2006. Gap between tourism planning and implementation: A case of China. Tourism Management, 27:1171-1180. doi: 10.1016/j.tourman.2005.11.009

Lillesand, T.M., W. Kiefer and J.W. Chipman. 2004. Remote Sensing and Image Interpretation (Fifth Edition). John Wiley \& Sons, Inc., New Work.

Liu, A. and G. Wall. 2006. Planning tourism employment: a developing country perspective. Tourism Management, $\quad$ 27(1): 159-170. https://doi.org/10.1016/j.tourman.2004.08.004

LPEM UI - Lembaga Penyelidikan Ekonomi dan Masyarakat Fakultas Ekonomi dan Bisnis Universitas Indonesia. 2018. Laporan Akhir Kajian Dampak Sektor Pariwisata Terhadap Perekonomian Indonesia. Universitas Indonesia. Jakarta

Mai, T. and C. Smith. 2018. Scenario-based planning for tourism development using system dynamic modelling: A case study of Cat Ba Island, Vietnam. Tourism Management, 68: 336-354. https://doi.org/10.1016/j.tourman.2018.04.005.

Maguidad, V.M. 2013. Tourism planning in archipelagic Phillippines: A case review. Tourism Management Perspectives, 7: 25-33. https://doi.org/10.1016/j.tmp.2013.03.003

Mulya, S.P., E. Rustiadi dan A.E. Pravitasari. 2019. Perbandingan land rent pertanian dan non pertanian di Kabupaten Bogor dan Kota Bogor. Prosiding Seminar Nasional Asosiasi Sekolah Perencanaan Indonesia (ASPI) 2019. Hal 513-517. 3 Oktober 2019. Universitas Tanjungpura, Pontianak.

Oyola, M.L., F.J. Blancas, M. Gonzales and R. Caballero. 2012. Sustainable tourism indicators as planning tools in cultural destinations. Ecological Indicators, 18: 659-675. https://doi.org/10.1016/j.ecolind.2012.01.014

Papageorgiou, M. 2016. Coastal and marine tourism: A challenging factor in marine spatial planning. Ocean and Coastal Management, 129: 44-48. https://doi.org/10.1016/j.ocecoaman.2016.05.006.

Rahmafitria, F., P.L. Pearce, H. Oktadiana and H.P.H. Putro. 2020. Tourism planning and planning theory: Historical roots and contemporary aligment. Tourism Management Perspectives, Vol 35. https://doi.org/10.1016/j.tmp.2020.100703. 
Rangkuti, F. 2011. SWOT Balanced Scorecard Teknik Menyusun Strategi Korporat Yang Efektif Plus Cara Mengelola Kinerja dan Risiko. PT. Gramedia Pustaka Utama, Jakarta.

Supriatna, J. Supriatna, R.H. Koestoer and N.D. Takarina. 2016. Spatial dynamics model for sustainability landscape in Cimandiri Estuary, West Java, Indonesia. Procedia-Social and Behavioural Sciences, 227: 19-30. doi: 10.1016/j.sbspro.2016.06.038.
Sutanto. 1981. Aplikasi Penginderaan Jauh Untuk Dalam Perencanaan Kota. Fakultas Geografi UGM, Yogyakarta.

Yulianda, F., A. Fahrudin, A. Hutabarat, A. Armin, H. Sri, K. Kusharjani dan H. Sang. 2010. Pengelolaan Pesisir dan Laut Secara Terpadu. Book 3. Pusdiklat Kehutanan-Departemen Kehutanan RISECEMKorea International Coorporation Agency, Bogor. 